\title{
Aspek Hukum Sertifikat Layak Fungsi (SLF) Bangunan Dalam Rangka Penghindaran Kecelakaan Kerja
}

\author{
Kanyaka Prajnaparamita \\ Fakultas Hukum, Universitas Diponegoro \\ anya_fh@yahoo.com
}

\begin{abstract}
Building function feasibility certificate is a certificate that is regulated by the regional government except for special function buildings by the government to declare the proper functioning of a building both administratively and technically, before its utilization. The research method used is normative legal research using a practical legal approach. The results of the study indicate that the building-worthy certificate or the term SLF has a legal basis in its arrangement. SLF is based on Law Number 26 of 2007 concerning Spatial Planning, Law Number 25 of 2009 concerning Public Services and Law Number 1 of 2011 concerning Housing and Settlement Areas.
\end{abstract}

Keywords: Function Worthy Certificate (SLF), Law, Building, Work Accident

\begin{abstract}
Abstrak
Sertifikat laik fungsi gedung merupakan sertifikat yang ditertibkan oleh pemerintah daerah kecuali untuk bangunan fungsi khusus oleh pemerintah untuk menyatakan kelaikan fungsi suatu bangunan gedung baik secara administratif maupun teknis, sebelum pemanfaatannya. Metode penelitian yang digunakan adalah penelitian hukum normatif menggunakan pendekatan praktis hukum. Hasil penelitian menujukan bahwa Sertifikat laik fungsi gedung atau dengan istilah SLF memiliki landasan hukum dalam pengaturannya. SLF bedasarkan pada Undang-Undang Republik Indonesia Nomor 28 Tahun 2002 Tentang Bangunan Gedung, Undang-undang Nomor 26 tahun 2007 tentang Penataan Ruang, Undang-undang Nomor 25 tahun 2009 tentang Pelayanan Publik dan Undang-undang Nomor 1 tahun 2011 tentang Perumahan dan Kawasan Permukiman.
\end{abstract}

Kata kunci: Sertifikat layak fungsi (SLF), hukum, Bagunan, Gedung, Kecelakaan kerja 


\section{A. Pendahuluan}

Pembangunan nasional untuk memajukan kesejahteraan umum sebagaimana dimuat di dalam Undang-Undang Dasar 1945 pada hakekatnya adalah pembangunan manusia Indonesia seutuhnya dan pembangunan seluruh masyarakat Indonesia yang menekankan pada keseimbangan pembangunan, kemakmuran lahiriah dan kepuasan batiniah, dalam suatu masyarakat Indonesia yang maju dan berkeadilan sosial berdasarkan Pancasila. Bangunan gedung sebagai tempat manusia melakukan kegiatannya, mempunyai peranan yang sangat strategis dalam pembentukan watak, perwujudan produktivitas, dan jati diri manusia. Oleh karena itu, penyelenggaraan bangunan gedung perlu diatur dan dibina demi kelangsungan dan peningkatan kehidupan serta penghidupan masyarakat, sekaligus untuk mewujudkan bangunan gedung yang fungsional, andal, berjati diri, serta seimbang, serasi, dan selaras dengan lingkungannya. Bangunan gedung merupakan salah satu wujud fisik pemanfaatan ruang.

Pengaturan bangunan gedung tetap mengacu pada pengaturan penataan ruang sesuai peraturan perundang-undangan yang berlaku. Untuk menjamin kepastian dan ketertiban hukum dalam penyelenggaraan bangunan gedung, setiap bangunan gedung harus memenuhi persyaratan administratif dan teknis bangunan gedung, serta harus diselenggarakan secara tertib. Undang-undang tentang Bangunan Gedung mengatur fungsi bangunan gedung, persyaratan bangunan gedung, penyelenggaraan bangunan gedung, termasuk hak dan kewajiban pemilik dan pengguna bangunan gedung pada setiap tahap penyeleng-garaan bangunan gedung, ketentuan tentang peran masyarakat dan pembinaan oleh pemerintah, sanksi, ketentuan peralihan, dan ketentuan penutup.

Keseluruhan maksud dan tujuan pengaturan tersebut dilandasi oleh asas kemanfaatan, keselamatan, keseimbangan, dan keserasian bangunan gedung dengan lingkungannya, bagi kepentingan masyarakat yang berperikemanusiaan dan berkeadilan. Masyarakat diupayakan untuk terlibat dan berperan secara aktif bukan hanya dalam rangka pembangunan dan pemanfaatan bangunan gedung untuk kepentingan mereka sendiri, tetapi juga dalam meningkatkan pemenuhan persyaratan bangunan gedung dan tertib penyelenggaraan bangunan gedung pada umumnya. 
Perwujudan bangunan gedung juga tidak terlepas dari peran penyedia jasa konstruksi berdasarkan peraturan perundang-undangan di bidang jasa konstruksi baik sebagai perencana, pelaksana, pengawas atau manajemen konstruksi maupun jasa-jasa pengembangannya, termasuk penyedia jasa pengkaji teknis bangunan gedung. Oleh karena itu, pengaturan bangunan gedung harus berjalan seiring dengan pengaturan jasa konstruksi sesuai dengan peraturan perundang-undangan. Dengan diberlakukannya Undang-Undang Republik Indonesia Nomor 28 Tahun 2002 Tentang Bangunan Gedung, maka semua penyelenggaraan bangunan gedung baik pembangunan maupun pemanfaatan, yang dilakukan di wilayah negara Republik Indonesia yang dilakukan oleh pemerintah, swasta, masyarakat, serta oleh pihak asing, wajib mematuhi seluruh ketentuan yang tercantum dalam Undang-undang tentang Bangunan Gedung. Dalam menghadapi dan menyikapi kemajuan teknologi, baik informasi maupun arsitektur dan rekayasa, perlu adanya penerapan yang seimbang dengan tetap mempertimbangkannilai-nilai sosial budaya masyarakat setempat dan karakteristik arsitektur dan lingkungan yang telah ada, khususnya nilai-nilai kontekstual, tradisional, spesifik, dan bersejarah. Pengaturan dalam undang-undang juga memberikan ketentuan pertimbangan kondisi sosial, ekonomi, dan budaya masyarakat Indonesia yang sangat beragam. Berkaitan dengan hal tersebut, pemerintah terus mendorong, memberdayakan dan meningkatkan kemampuan masyarakat untuk dapat memenuhi ketentuan dalam undang-undang secara bertahap sehingga jaminan keamanan, keselamatan, dan kesehatan masyarakat dalam menyelenggarakan bangunan gedung dan lingkungannya dapat dinikmati oleh semua pihak secara adil dan dijiwai semangat kemanusiaan, kebersamaan, dan saling membantu, serta dijiwai dengan pelaksanaan tata pemerintahan yang baik.

Dalam rangka mengusahakan jaminan keamanan, keselamatan, dan kesehatan masyarakat dalam menyelenggarakan bangunan gedung dan lingkungannya dapat dinikmati oleh semua pihak secara adil dan dijiwai semangat kemanusiaan, maka tulisan ini hendak menguraikan tentang sertifikat layak fungsi gedung (SLF) merupakan sertifikat yang ditertibkan oleh pemerintah daerah kecuali untuk bangunan fungsi khusus oleh pemerintah untuk menyatakan kelaikan fungsi suatu bangunan gedung baik secara administratif maupun teknis, sebelum pemanfaatannya. Sertifikat laik fungsi gedung atau dengan istilah SLF memiliki landasan hukum dalam pengaturannya. SLF bedasarkan pada 
Undang-Undang Republik Indonesia Nomor 28 Tahun 2002 Tentang Bangunan Gedung, Undang-undang Nomor 26 tahun 2007 tentang Penataan Ruang, Undang-undang Nomor 25 tahun 2009 tentang Pelayanan Publik dan Undang-undang Nomor 1 tahun 2011 tentang Perumahan dan Kawasan Permukiman.

\section{B. Pembahasan}

\section{Landasan Penghidaran Kecelakaan Kerja}

Salah satu faktor yang mempengaruhi produktivitas kerja adalah keselamatan kerja. Perusahaan perlu memelihara kesehatan para karyawan, kesehatan ini menyangkut kesehatan fisik ataupun mental. Kesehatan para karyawan yang buruk akan mengakibatkan kecenderungan tingkat absensi yang tinggi dan produksi yang rendah. Adanya program kesehatan yang baik akan menguntungkan para karyawan secara material, karena mereka akan lebih jarang absen bekerja dengan lingkungan yang menyenangkan, sehingga secara keseluruhan akan mampu bekerja lebih lama berarti lebih produktif. Keselamatan kerja erat kaitannya dengan peningkatan produksi dan produktivitas. Sebagaimana juga yang merupan amanat dari Undang Undang Nomor 13 Tahun 2003 Tentang ketenagakerjaan.

Dengan tingkat keselamatan kerja yang tinggi, kecelakaan yang dapat menyebabkan sakit, cacat dan kematian pada pekerja dapat ditekan sekecil-kecilnya. Tingkat keselamatan yang tinggi sejalan dengan pemeliharaan dan penggunaan peralatan kerja, mesin yang produktif dan efisien, bertalian dengan tingkat produksi dan produktivitas yang tinggi. Masih tingginya angka kecelakaan kerja pada pekerja konstruksi di Indonesia, serta adanya tuntutan global dalam perlindungan tenaga kerja, maka diperlukan upaya-upaya untuk meminimalisasi kecelakaan kerja. Faktor sumber daya manusia memegang peranan yang sangat penting dalam meminimalisasi kecelakaan kerja, seperti kurangnya kesadaran untuk bekerja dalam kondisi sehat sampai dengan tidak menggunakan alat pelindung diri saat bekerja. Dari sekian banyak faktor penyebab kecelakaan kerja akan dilakukan suatu penelitian tentang analisis upaya pencegahan kecelakaan kerja difokuskan pada faktor Kesehatan Kerja, Pelatihan dan Penggunaan Alat Pelindung Diri (APD). 
Landasan dari adanya aturan tentang kesehatan dan keselamatan berdasarkan pada Undang Undang Nomor 1 tahun 1970 tentang keselamatan kerja. Yang bertujuan untuk

a. setiap tenaga kerja berhak mendapat perlindungan atas keselamatannya dalam melakukan pekerjaan untuk kesejahteraan hidup dan meningkatkan produksi serta produktivitas Nasional

b. setiap orang lainnya yang berada di tempat kerja terjamin pula keselamatannya

c. setiap sumber produksi perlu dipakai dan dipergunakan secara aman dan efisien berhubung dengan itu perlu diadakan segala daya upaya untuk membina normanorma perlindungan kerja;

d. pembinaan norma-norma itu perlu diwujudkan dalam Undang-undang yang memuat

e. ketentuan-ketentuan umum tentang keselamatan kerja yang sesuai dengan perkembangan masyarakat. Industrialisasi. teknik dan teknologi

\section{Sertifikat Layak Funsi Bangunan}

Untuk mendapatkan sertifikan Layak Fungsi Bangunan (SLF), pemerintah telah mengaturanya dalam Peraturan Menteri Pekerjaan Umum Nomor:25/PRT/M/2007 Tentang Pedoman Sertifikat Laik Fungsi Bangunan Gedung. Adapun tujuan aturan tersebut adalah 1). untuk terwujudnya bangunan gedung yang andal harus memenuhi persyaratan teknis administratif bangunan gedung sesuai dengan fungsinya; 2). Bangunan gedung sebelum dimanfaatkan harus diterbitkan Sertifikat Laik Fungsi bangunan gedung; dan 3). Pemerintah daerah sesuai kewenangannya,menetapkan Sertifikat Laik Fungsi bangunan gedung.

Jika dihubungkan dengan hukum ketenagakerjaan dalam hal ini adalah keselamatan dan kerja maka dapat dipahami bahwa salah sarat adanya keselamatan dan kesehatan kerja adalah adanya kondisi bangunan yang layak sebagai tempat kerja, sebagaimana ketentuan hukum ketenagakerjaan. Dalam hukum ketenagakerjaan, keselamatan dan kesehatan kerja merupakan suatu kondisi dalam pekerjaan yang sehat dan aman baik itu bagi pekerjaannya, perusahaan maupun bagi masyarakat dan lingkungan sekitar pabrik atau tempat kerja tersebut. Keselamatan dan kesehatan kerja juga merupakan suatu usaha untuk mencegah setiap perbuatan atau kondisi tidak 
selamat, yang dapat mengakibatkan kecelakaan. Dalam hal ini SLF merupakan syarat dari adanya kesehatan dan keselamatan kerja.

Sertifikat Laik Fungsi bangunan gedung yang diberikan oleh pemerintah daerah, oleh Pemerintah dan pemerintah provinsi untuk bangunan gedung fungsi khusus, kepada pemilik/pengguna bangunan gedung meliputi: (- Penerbitan SLF untuk pertama kali; dan - Perpanjangan SLF selanjutnya). Dalam proses pemberian SLF bangunan gedung pemerintah daerah, Pemerintah dan pemerintah provinsi untuk bangunan gedung fungsi khusus, harus melaksanakan dengan prinsip pelayanan prima, serta tidak ada pungutan biaya.

\section{Simpulan}

Sertifikat laik fungsi gedung (SLF) atau dengan istilah SLF memiliki landasan hukum dalam pengaturannya. SLF meliki landasan hukum yaitu bedasarkan pada Undang-Undang Republik Indonesia Nomor 28 Tahun 2002 Tentang Bangunan Gedung, Undang-undang Nomor 26 tahun 2007 tentang Penataan Ruang, Undang-undang Nomor 25 tahun 2009 tentang Pelayanan Publik dan Undang-undang Nomor 1 tahun 2011 tentang Perumahan dan Kawasan Permukiman. Adapun tujuan diadakannya SLF adalah 1). untuk terwujudnya bangunan gedung yang andal harus memenuhi persyaratan teknis administratif bangunan gedung sesuai dengan fungsinya; 2). Bangunan gedung sebelum dimanfaatkan harus diterbitkan Sertifikat Laik Fungsi bangunan gedung; dan 3). Pemerintah daerah sesuai kewenangannya,menetapkan Sertifikat Laik Fungsi bangunan gedung.

\section{Daftar Pustaka}

Khadiyanto, Parfi, Kajian Teknis Pembangunan Gedung.

Peraturan Menteri Dalam Negeri Nomor 32 Tahun 2010 Tentang Pedoman Pemberian Izin Mendirikan Bangunan.

Peraturan Menteri PU Nomor 26/prt/m/2007 Tentang Pedoman Tim Ahli Bangunan Gedung.

Peraturan Menteri Pekerjaan Umum Nomor: 29/PRT/M/2006 Tentang Pedoman Persyaratan Teknis Bangunan Gedung.

Suprapto, 2008. Tinjauan Eksistensi Standar-standar (SNI) Proteksi Kebakaran dan Penerapannya Dalam Mendukung Implementasi Peraturan Keselamatan Bangunan. Prosiding.

Undang Undang Nomor 1 tahun 1970 tentang keselamatan kerja 
Undang-Undang Republik Indonesia Nomor 28 Tahun 2002 Tentang Bangunan Gedung,

Undang-undang Nomor 26 tahun 2007 tentang Penataan Ruang, ndang-undang Nomor 13 tahun 2003 tentang Ketenagakerjaan

Undang-undang Nomor 25 tahun 2009 tentang Pelayanan Publik

Undang-undang Nomor 1 tahun 2011 tentang Perumahan dan Kawasan Permukiman. 